\title{
Dioses y ciudad en la Bética romana. Las estatuas de dioses en los espacios públicos de las ciudades béticas
}

\author{
Mercedes Oria Segura \\ Universidad de Sevilla *
}

\section{Resúmen}

El artículo estudia las representaciones escultóricas de dioses destinadas a espacios públicos de las ciudades de la Bética, tanto las conservadas como las conocidas a través de inscripciones. Se han seleccionado únicamente esculturas de tamaño medio o grande, adecuadas para la exhibición pública, e imágenes de dioses efectivamente venerados como tales en la Bética, con vistas a comprobar si existe o no una relación entre el culto y la disposición pública de estatuas. Se revisa el repertorio de dioses y los lugares concretos en que se han encontrado sus estatuas o pedestales. La conclusión se refiere al carácter de la estatuaria pública, en este caso la de tema mitológico, como manifestación cívica por encima de su valor religioso.

\section{Summary}

This paper reviews the statues of the gods in public places of Baetican towns, either those preserved until our days, either the ones that we know only by inscriptions. Only big or middle size statues, the most adapted to public exhibition, representing gods actually worshipped in Baetica, had been selected, in order to search for an hypotetic connection between cult and public disposal of statues. It revises the gods' list and the specific places where the statues and basis are situated. The final conclusion refers to the function of public, mythological statuary, as a civic demonstration, beyond its religious rol.

\section{LAS IMÁGENES DE DIOSES EN LOS AMBIENTES URBANOS ROMANOS}

Los habitantes de la Bética, como tantos otros ciudadanos del Imperio Romano, viven literalmente rodeados por los dioses. Estos se acumulan en sus casas, en sus calles y en los edificios de uso común, ya sean religiosos, políticos, sedes para espectáculos y deportes, jardines, pórticos y ninfeos. Todos ellos pueden calificarse de forma genérica como "espacios públicos" o "espacios cívicos” (Zaccaria Ruggiu, 1995, esp. Caps. 1, 3, 5). Conservamos numerosas pruebas de esta profusa decoración mitológica, en especial las propias esculturas, así como pedestales y otras dedicatorias más o menos explícitas de estatuas. Otros

* Departamento de Prehistoria y Arqueología, grupo de investigación "De la Turdetania a la Bética", en cuyo proyecto "La formación de la Bética romana" (Junta de Andalucía, II Plan Andaluz de Investigación, elementos en la misma línea son las aras decoradas (v. en general Dräger, 1994, esp. Cap. III sobre los lugares en que se colocan), mosaicos y pinturas de tema mitológico, etc. La pintura mural recrea en muchos casos una imagen idealizada de los ambientes decorados con estatuas, especialmente los jardines dionisíacos reproducidos en pinturas de los estilos III y IV, más frecuentes fuera de la P. Ibérica que dentro de la misma (Moormann, 1988, Caps. I, III; el repertorio de dioses representados, en pp. 50-56). Por el contrario, los textos contemporáneos apenas dan ninguna noticia respecto a esculturas, y mucho menos sobre la reacción que provocan entre el público hispano al que se destinan.

El objetivo de este trabajo es proponer unas

HUM-152; Ministerio de Educación, D.G.E.S., Programa de Promoción General del Conocimiento, PB98-0736) se encuadra este trabajo. 
líneas de estudio, poco frecuentadas hasta ahora salvo excepciones (p.e. Rodríguez Oliva, 1993), para la estatuaria pública de la Bética, en particular las representaciones de dioses. Analizar la estatuaria romana de tema mitológico supone entrar en varios terrenos igualmente complejos. El primero es el del concepto y la representación de la divinidad y la forma de rendirle culto, que puede incluir o no imágenes. En el ámbito romano, éstas se generalizan a partir del s. IV a.C., adaptando a las propias necesidades las iconografías griegas. Muy modestas en sus inicios, con predominio de las figuras de terracota y madera, desde principios del s. II a.C. se generalizan según Plinio (NH XXXIII, 148) las de bronce, favorecidas por la expansión de la llamada luxuria asiática. Estas imágenes residen en los templos, son las destinatarias de sacrificios y ofrendas y a veces participan incluso en solemnes procesiones y banquetes, como ocurre en los lectisternia republicanos y en los cultos de origen oriental ( $\mathrm{v}$. en general sobre las imágenes de culto romanas Martin, 1987 y Vermeule, 1987).

Pero además, las imágenes de dioses y mitológicas en general sobrepasan la función religioso-cultual, para desempeñar otras en los ámbitos público y privado. De estas nos ocuparemos fundamentalmente a lo largo del estudio, más que de la vertiente propiamente religiosa, aunque es innegable cierto carácter alusivo cuando se habla de representaciones divinas (Vickers, 1987, 20; sobre la doble vertiente religiosa y cultural de unas piezas equiparables como son las aras decoradas, Dräger, 1994, 176). Podemos resumir así las funciones de las esculturas de tema mitológico dentro del mundo romano, en grado "decreciente" en cuanto a su valoración religiosa:

- imágenes de culto

- exvotos

- decoración con trasfondo religioso: exterior de templos, alusiones a cultos acuáticos o salutíferos en termas y ninfeos, sedes colegiales, etc.

- decoración alusiva a valores políticos: cultos cívicos, personificaciones de virtudes públicas e imperiales, divinidades de pueblos vencidos, etc.

- imágenes clásicas de dioses exhibidas por su valor artístico en pórticos, jardines, edificios públicos y privados, etc.

Las diversas funciones no son incompatibles, como demuestran los templos y su decoración, concebida ya desde época helenística con auténtico sentido expositivo paralelo a su contenido simbólico (Cain, 1995, 123). Pausanias es suficientemente expresivo al admirar como obras de arte las más famosas imágenes de los templos griegos, que ya en su época ejercían un auténtico atractivo "turístico" (Descripción de Grecia, I, XXII, 4 - XXVIII, 3, descripción de la Acrópolis de Atenas; V, X, 1 - XII, 6, el santuario de Zeus en Olimpia, etc.).

Lugar de colocación, asociaciones con otras imágenes, tamaños y materiales empleados, etc. forman un auténtico código de señales entre los responsables de las imágenes y sus destinatarios. Descifrar ese código supone adentrarse en una compleja trama de relaciones sociales que se expresan, entre otros medios, mediante imágenes (Thelamon - Schmitt - Pantel, 1983, 17; Pairault Massa, 1992, 11-13; Zanker, 1994, 281). En el mundo romano, las "reglas del juego" se establecen en un ambiente muy concreto: el de una ciudad-Estado en amplia e imparable expansión, cuyas élites dirigentes se enzarzan progresivamente en una lucha por el poder político, donde el prestigio y la imagen pública son un componente fundamental (Hölscher, 1994, Cap. 1). La escultura no es ni mucho menos la única manifestación, pero sí uno de los elementos más visibles del paisaje urbano romano. Los retratos individuales con fines propagandísticos más o menos declarados son su cara más evidente, pero las imágenes públicas comprenden un repertorio mucho más amplio, incluyendo las mitológicas y propiamente divinas como expresión de tendencias ideológicas (Pairault Massa, 1992, Cap. 6). Los líderes políticos utilizan la imagen de los dioses protectores de sus familias, de los que llegan a declararse descendientes, y fomentan su culto público mediante la dedicatoria de templos, altares y esculturas. Por otra parte, la presencia de imágenes de los dioses en los más diversos edificios públicos, seleccionadas por su adecuación al entorno y funciones, decus, los eleva de la esfera cotidiana (Hesberg, 1981, 1036-1037), creando un ambiente que no es cultual en sentido estricto, pero sí expresión general de pietas (referido a las aras con relieves, Dräger, 1994, 28-30).

Estas reglas son trasplantadas a las provincias del Imperio con diverso éxito, dependiendo de que en ellas exista o no una estructura previa (política, urbana, cultural) compatible con la romana. Los dirigentes locales reproducen y adaptan a su propio entorno los esquemas vigentes en ámbitos públicos y privados, mientras es difícil evaluar cómo los aceptan e interpretan las capas más amplias de la población, a partir de la documentación conservada (una llamada de atención sobre este problema, en Gregory, 1994). Dependiendo del destino de la estatua, su público será más o menos amplio y puede mostrarse o no receptivo a su mensaje, según sus pro- 
pias coordenadas culturales. Éstas pueden hacer variar el significado de las imágenes, desde la intención primitiva de su responsable, hasta la interpretación y el uso que hacen de las mismas sus receptores (v. el caso de la iconografía de las cerámicas griegas, reinterpretada por sus compradores ibéricos: Olmos, 1991, 213-216).

Aplicado al caso de la Bética y siguiendo la metodología propuesta por Coarelli (1990/1996, 17-18) para el estudio de los procesos de "aculturación", trataremos de comprobar cuáles son las imágenes divinas preferidas por los béticos de época imperial, si corresponden a dioses efectivamente venerados o son meras alusiones políticas o culturales. La tradición en el uso público de imágenes de dioses o la inexistencia de la misma, la incorporación de atributos locales a figuras clásicas o, por el contrario, la romanización de divinidades locales, la propia inclusión o no de éstas en los ambientes públicos, son aspectos fundamentales a tener en cuenta. En este sentido, el mayor problema es la escasa información sobre la religiosidad prerromana de la futura Bética. Apenas se conocen representaciones de dioses en este ámbito hasta época muy tardía, ya republicana, exceptuando las de tradición feniciopúnica con sus asimilaciones posteriores. La implantación oficial de los cultos romanos, que acompaña a los cambios de estatuto jurídico de las ciudades, sería la responsable directa de que se adoptasen las iconografías divinas, junto con los usos no estrictamente religiosos de las mismas, y de esta premisa parte nuestro trabajo. Intentaremos cuando sea posible reconstruir los contextos a los que pertenecen las imágenes, fundamentales a la hora de establecer su significado. En definitiva, se trata de comprobar cómo valoran los habitantes de la Bética la estatuaria mitológica pública, en el contexto social e histórico de las ciudades organizadas a la manera romana. Es decir, qué nos dicen las imágenes de dioses y su forma de uso sobre la mentalidad de los hispanorromanos y su expresión pública.

\section{LOS DIOSES Y SU IMAGEN EN LAS CIU- DADES BÉTICAS}

El material que analizamos a continuación abarca a grandes rasgos todo el período altoimperial, con especial concentración en el s. II d.C. Hemos incluido solamente estatuas que superan $1 \mathrm{~m}$. de altura total (completas o de tamaño calculable a partir de los fragmentos conservados), más adecuadas para la exhibición pública y para el tipo de pedestales que conservamos, mientras las piezas de menor tamaño y las hermas se consideran preferentemente de carácter doméstico, según los criterios establecidos por Bartman (1992, 39-48, esp. 43 ss.) en su estudio sobre las copias "en miniatura" de uso decorativo. En la estatuaria mitológica se incluyen numerosos semidioses, héroes y figuras secundarias, pero en este estudio hemos seleccionado sólo las imágenes de divinidades propiamente dichas, con vistas a matizar si existe o no alguna relación entre el culto, que las figuras secundarias no reciben, y la iconografía.

\subsection{Los dioses}

La Tabla I nos muestra, a manera de cuadro sinóptico, el total de estatuas de dioses conocidas en la Bética: 153 entre estatuas conservadas (48) e inscripciones que las mencionan (105), correspondientes a un grupo de 35 divinidades individuales o colectivas; estas últimas, las Ninfas y menciones a grupos de dioses y diosas sin determinar (CIL II 3359 y CIL II 5513, de la provincia de Jaén; CIL II 1649 y CIL II 2098, compuesta por una donación de cinco estatuas, ambas en la provincia de Córdoba).

Lo primero que llama la atención en la Tabla I es la completa ausencia de dioses indígenas, según la tónica general en la Bética. Los dioses propiamente locales son muy difíciles de identificar para la etapa prerromana, con grandes desigualdades según las zonas y el trasfondo cultural turdetano, ibérico o fenicio-púnico. Su culto parece haber desaparecido casi por completo en época imperial, excepto en el caso de Melqart / Hércules Gaditano y el más problemático de Tanit / Dea Caelestis, que experimentan grandes transformaciones formales y de contenido. De las pocas imágenes prerromanas conservadas es muy difícil asegurar si representan a un dios de origen local. Desarrollamos con más amplitud este tema en otro trabajo en preparación (Oria, e.p.). Sin embargo, es necesario constatar que la desaparición de los cultos prerromanos en ambientes urbanos no es exclusiva de la Bética y se vincula al carácter y sobre todo a la función de los dioses venerados públicamente en las ciudades romanas.

Los más representados son dioses de gran popularidad como Venus (12 ejemplares), Diana, Minerva (9 ejemplos cada una), Apolo, Marte, Júpiter, Juno, las Ninfas (8 casos cada uno), Mercurio ( 7 imágenes), Fortuna, Hércules (6 ejemplos por cabeza) y la Piedad (5 ejemplos), superados todos ellos con mucho por las 18 estatuas conocidas que se dedican a los distintos Genios ciudadanos. El resto de las divinidades aparecen aisladamente, con uno o dos casos cada una. En el repertorio son frecuentes las de carác- 


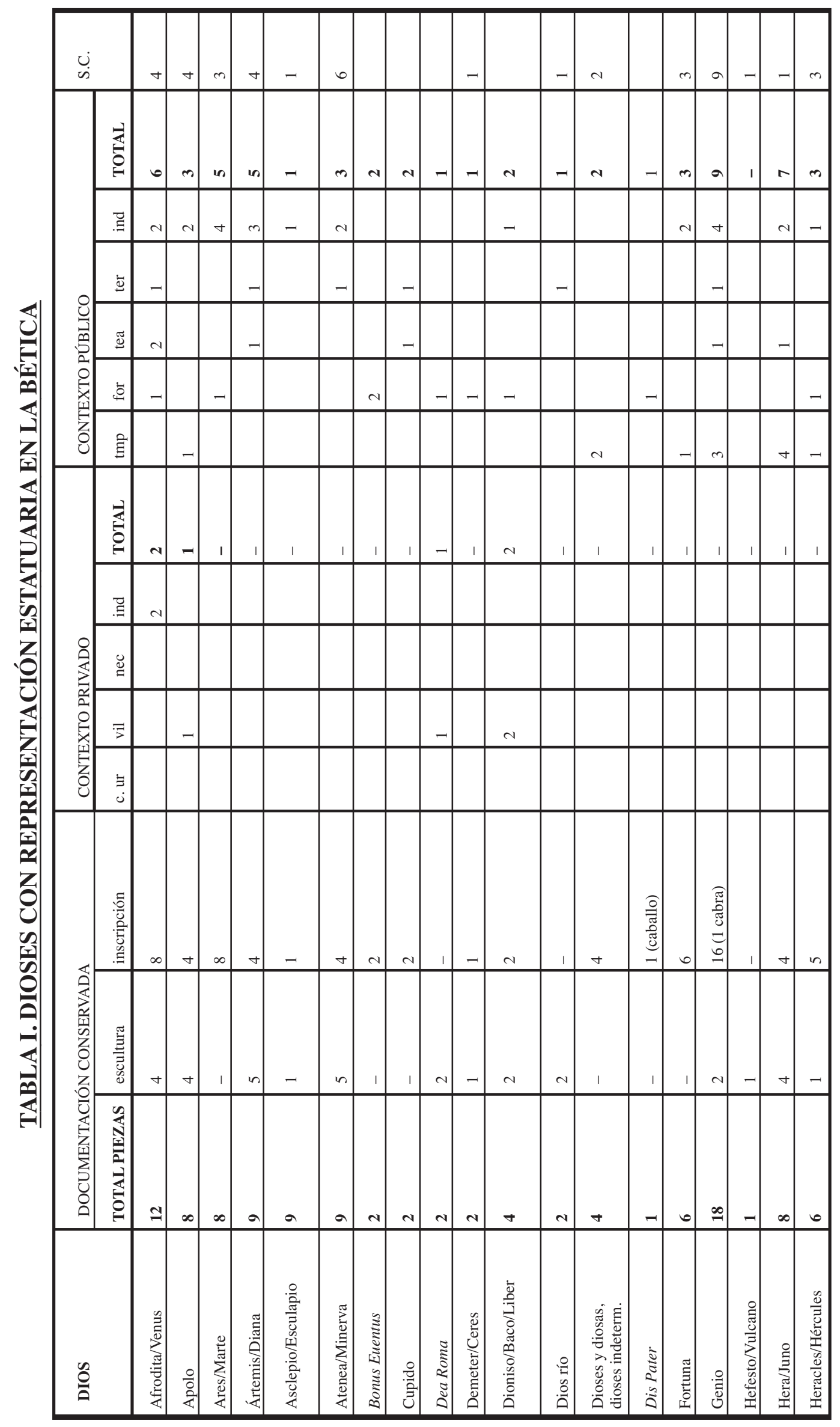




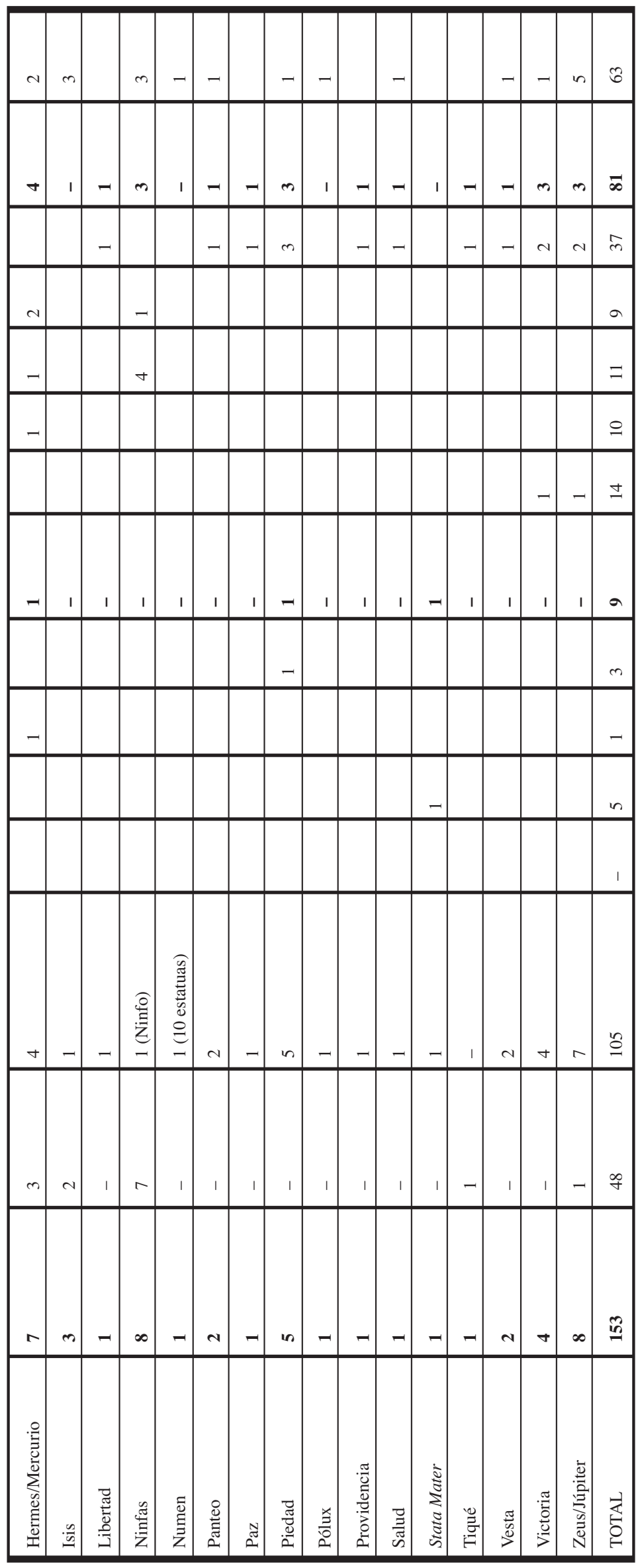


ter mixto religioso-político, las abstracciones personificadas o Virtudes que tanto favorece el culto imperial (v. en general Fears, 1981): Libertad, Paz, Piedad, Providencia, Salud, etc., que suman un total de 20 imágenes. Tal como indican los exvotos epigráficos encontrados por toda la provincia, al margen de las dedicatorias de estatuas todos estos dioses reciben culto regularmente en las ciudades de la Bética, por parte de personas de distintos orígenes: con preferencia ciudadanos con tria nomina y libertos con cargo de seuir Augustal, que añaden este calificativo a las divinidades honradas (v. las tablas finales de Rodríguez Cortés, 1991, 129-137). Sin embargo, la categoría de estas divinidades dentro del panteón es muy diferente y también su popularidad como objeto de culto, que no siempre coincide con el número de imágenes conservadas. Mientras la proporción es equilibrada en el caso de los dioses "mayores", los más beneficiados por las dedicatorias de estatuas como exvoto público en el ambiente de los cultos cívicos, figuras secundarias desde el punto de vista religioso como las Ninfas poseen un número abundante de estatuas, cuyo contexto descarta su utilización religiosa.

Un caso peculiar es el de Dis Pater, único entre los cultos romanos de la Bética e incluso del resto de Hispania. El nombr alude al carácter de Hades-Plutón como señor de las riquezas subterráneas y en las raras representaciones conservadas muestra la típica iconografía del dios infernal asociado a su pareja Perséfone-Proserpina (v. Belloni, 1986, LIMC III "Dis Pater" 1 y 2). El pedestal conservado en Munigua (CILA II.4, 1056) corresponde por su forma y las huellas de su superficie a la figura de un caballo, que para Grünhagen $(1976,236)$ representaba de forma simbólica al animal sacrificado habitualmente al dios. Su propuesta de relación con los "domadores de caballos" conocidos por relieves ibéricos (v. Marín-Padilla, 1997) es más discutible, por referirse a un ambiente y una tradición cultural bastante alejados de los detectables en Munigua. La donación incluía también un edificio, seguramente la propia sala en que se encontró, y un establo para el caballo. La advocación de Plutón escogida en este caso resulta apropiada en un centro de control minero como Munigua, aunque no se le conoce en otros distritos mineros de Hispania. Rodríguez Cortés $(1993,54)$ lo interpreta como el exvoto de un caballero, que agradece su acceso al orden ecuestre a una divinidad relacionada con la riqueza que ha permitido su ascenso social; riqueza originada en la minería, podríamos añadir. En la ciudad bética ocupa una posición muy destacada incluso físicamente, al situarse en una de las salas que se abren al foro.
Otra divinidad muy poco común es Stata Mater, cuyo pedestal (CIL $\mathrm{II}^{2} / 5$ 670) se conserva en Granada. En él se especifica que la imagen de la diosa va acompañada de adornos, probablemente joyas según conocemos a través de varias dedicatorias a otras diosas como Isis (CIL II 3386 y 3387, en Acci), Diana (Presedo, 1974, 195, en Barbesula), Venus Augusta (CIL II 2326, en Peñaflor), la Piedad Augusta (CIL II 1663, en Tucci) y la Victoria Augusta (Blanco, 1988, 110113, en Italica), una práctica especialmente propia de la Bética (v. Hoyo, 1994, 420- 422). Stata Mater es venerada en Roma como protectora contra el fuego, por parte de los responsables de la vigilancia contra incendios en época augustea, los magistri uicorum. Respecto a sus imágenes sólo conservamos una referencia literaria, por lo cual desconocemos su iconografía (v. Canciani, 1994, LIMC VII “Stata Mater" 1). En cualquier caso, la escasa información disponible nos la presenta como una diosa directamente ligada a un cargo municipal secundario y quizás en ese mismo ambiente se produzca la dedicación de Granada.

El número de dioses de los que se conservan esculturas es menor que el de aquellos mencionados en pedestales y dedicatorias. Divinidades y figuras mitológicas de distinta categoría cuyas esculturas en la Bética conocemos sólo por la epigrafía son Marte, Bonus Euentus, Cupido (como tal divinidad, no nos referimos aquí a las estatuillas de erotes tan frecuentes en la decoración doméstica), Dis Pater, Endovélico, Fortuna, Libertad, el Numen imperial, Panteo, Paz, Piedad, Pólux, Providencia, Salud, Stata Mater, Vesta y Victoria. Entre ellas predominan precisamente las de carácter más claramente político: las abstracciones divinizadas, Pólux como héroe protector de Roma, Vesta, el dios sincrético Panteo vinculado al culto imperial (Mangas, 1991, 130131). La desaparición de sus imágenes se relaciona probablemente con su material: metales preciosos, tan frecuentes en las donaciones públicas. Por su valor intrínseco, estos metales perduran mucho menos que el mármol y otras piedras semejantes, más habituales en cambio en las esculturas destinadas a la decoración arquitectónica. Lahusen (1992) defiende, basándose en ciertos comentarios de Plinio en el Libro XXXIV de la Historia Natural, que el mármol es el material más adecuado para las estatuas de dioses, mientras el bronce se prefiere para las honoríficas. Por el contrario, las dedicatorias conservadas nos muestran un uso preferente de los metales preciosos, que en todo caso podría incidir en la vertiente menos religiosa de estas esculturas. 


\subsection{Los lugares}

Lo que más nos interesa aquí es la localización de las estatuas. Prácticamente la mitad de las conservadas (23) carece de un contexto preciso, como puede comprobarse en la Tabla II, pero en todo caso las que se encuentran o pueden adscribirse a espacios públicos de distinto tipo superan con mucho (21 ejemplares) a las que proceden de ámbitos privados, viviendas o necrópolis (4 ejemplares). El carácter simbólico-político de las figuras representadas, Dea Roma (FernándezChicarro - Fernández, 1980, 44 n ${ }^{\circ}$ 3, de Carmo y León, 1995, $\mathrm{n}^{\mathrm{O}} 49$, de Italica) y la Tyché de Italica (León, 1995, nº 48), y el tamaño monumental de las piezas hacen que difícilmente pueda dudarse del destino público y la relación con la religión oficial de tres piezas de mármol, que no pueden asociarse a dedicatoria alguna y de las que sólo una, la Dea Roma de Italica, apareció con seguridad en un foro. En cambio las ninfas, relativamente abundantes (seis estatuas-fuente), y los dioses-río, de los que se conservan dos ejemplares de grandes dimensiones, son figuras características de la decoración de termas y teatros, pero no especialmente frecuentes en el ambiente de los cultos oficiales. De hecho dos ninfas de Italica (León, 1995, no 56-57) y otras dos de Corduba (Loza, 1993) se relacionan con los teatros de ambas ciudades. Sin embargo, en el foro de Hispalis se erigió una estatua de bronce al Genio del río Baetis (CIL II $1163=$ CILA II.4 1025, en Espartinas, sin contexto), cuya iconografía sería la habitual en estas divinidades fluviales y que sí se encontraba en este lugar en categoría de genio protector públicamente venerado.

Algo semejante ocurre con los pedestales y dedicatorias de estatuas, recogidas en la Tabla III, aunque en este caso el formulario empleado en muchos epígrafes, del tipo L.D.D.D., accepto loco y similares, contribuye a confirmar el destino público de pedestales conservados fuera de contexto. En conjunto, las dedicatorias de estatuas para lugares públicos son 60 , frente a 5 de carácter privado y 40 sin contexto conocido. Además, el contenido de la inscripción correspondiente puede aclarar si la estatua es un exvoto, una imagen de culto, un retrato divinizado en memoria de un difunto (Wrede, 1981) o para exaltar a un gobernante (Niemeyer, 1968; Mikocki, 1995), e incluso en ciertos casos el lugar concreto al que se destina (Oria, 1998). Su tamaño es indicativo del de la estatua que soporta. Es poco frecuente contar con escultura y pedestal asociados, pero sí pueden utilizarse como documentación complementaria.

$\mathrm{Si}$ atendemos a los lugares de uso público donde con seguridad se han situado estatuas o pedestales, o que son aludidos en las inscripciones correspondientes, encontramos lo siguiente:

- 14 piezas destinadas a templos

- 11 en teatros

- 10 en foros

- 9 en termas

- 37 en espacios públicos indeterminados, lo que suma un total de 81 piezas.

En cuanto a las de procedencia privada, son las siguientes:

- 5 estatuas en uillae

- 1 en necrópolis

- 3 en ámbitos privados indeterminados.

De las 63 piezas restantes desconocemos el lugar de aparición o colocación original.

\subsubsection{Los templos}

El predominio de los templos como lugar de hallazgo o destino de las estatuas de dioses es algo que no puede extrañar, ya que a simple vista se trata de su escenario "natural". En unos casos la escultura es propiamente la imagen de culto principal, en otros se trata de exvotos y decoración complementaria. Sin embargo en la Bética no son demasiado frecuentes las imágenes en contextos claramente cultuales. Debemos destacar los restos aparecidos en el llamado Capitolio de Baelo Claudia (Sillières, 1995, 93-95, partidario de mantener la identificación tradicional del templo, remitiendo a la futura monografía), fragmentos de dos esculturas femeninas que P. Paris identificó en 1917 con Juno y Minerva. Además de estos restos, las únicas esculturas en contexto cultual recogidas en nuestra Tabla II son las tres diosas sedentes de Cartima, que al parecer se situaban en un edificio con doble cabecera absidada y pavimento de mármol de colores (Rodríguez Oliva, 1993, 27). Igualmente se especuló durante mucho tiempo con que el edificio a espaldas de la cávea del teatro de Italica, en cuyo entorno se encontraron la conocida estatua de Diana (León, 1995, nº 40) y otras piezas claves de la estatuaria italicense como el Mercurio (id., $\mathrm{n}^{\mathrm{o}} 32$ ) y la Venus (id., $\mathrm{n}^{\mathrm{o}} 38$ ), fuese un templo dedicado a la primera diosa (Mélida, 1925, 66, seguido por Pena, 1981; Mangas, 1986, 322; Rodríguez Cortés, 1991, 50). Los investigadores más recientes han retomado esta idea, aunque sin precisar la divinidad titular del supuesto templo (Rodríguez Hidalgo - Keay, 1995, 412). En este caso, tendríamos aquí un complejo religioso en el que aparecen asociados Mercurio, Venus y Diana, tres dioses característicos del 


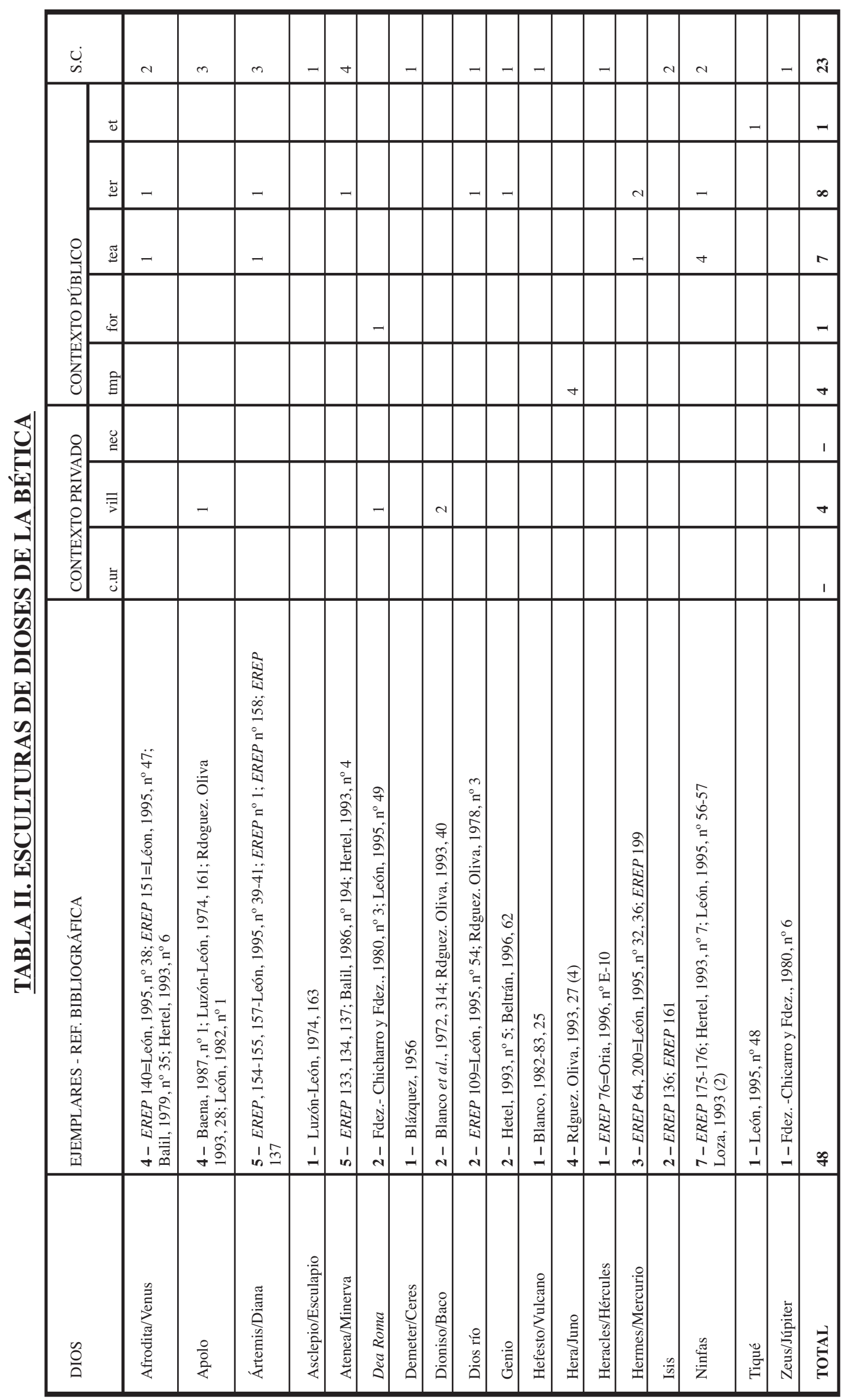




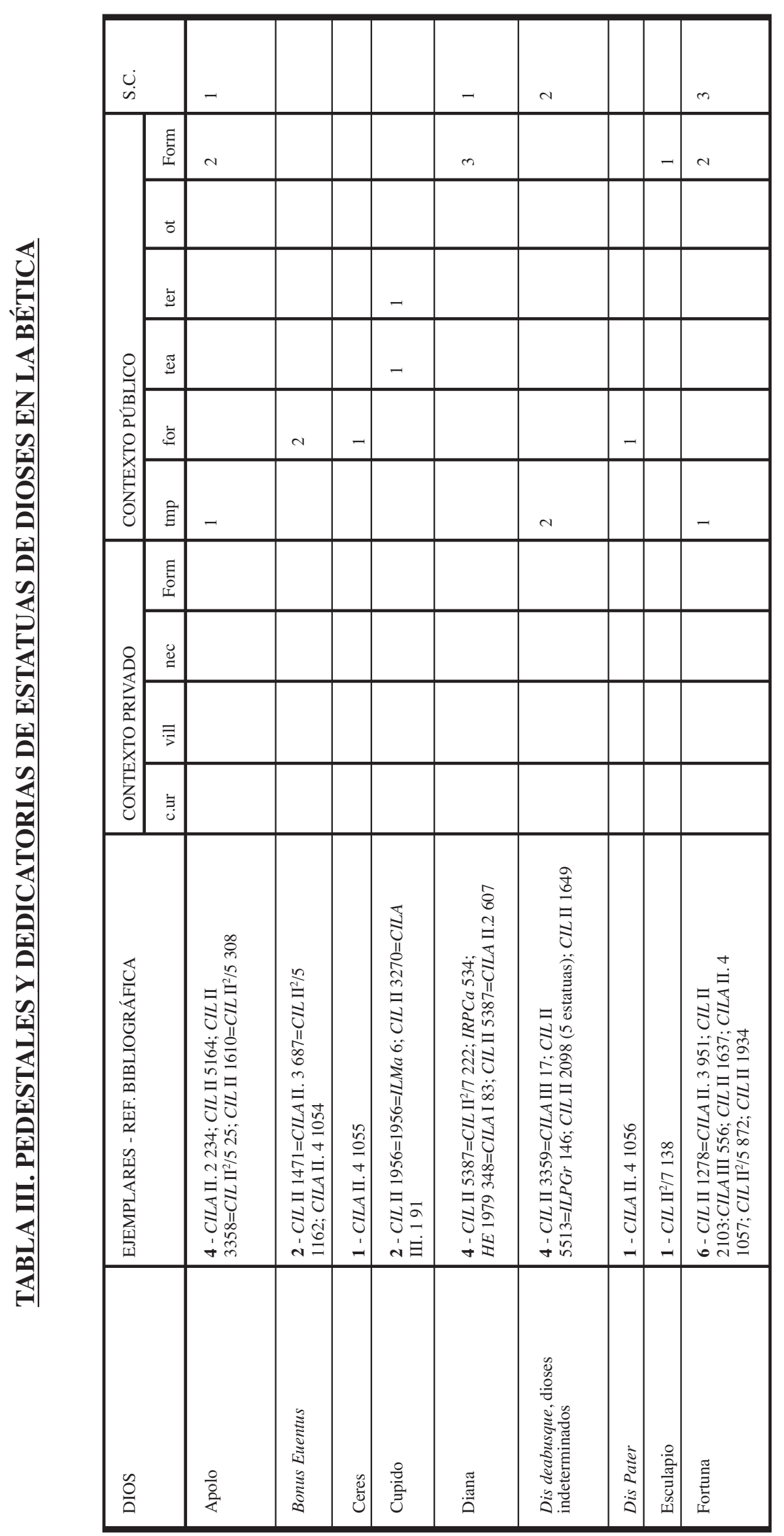




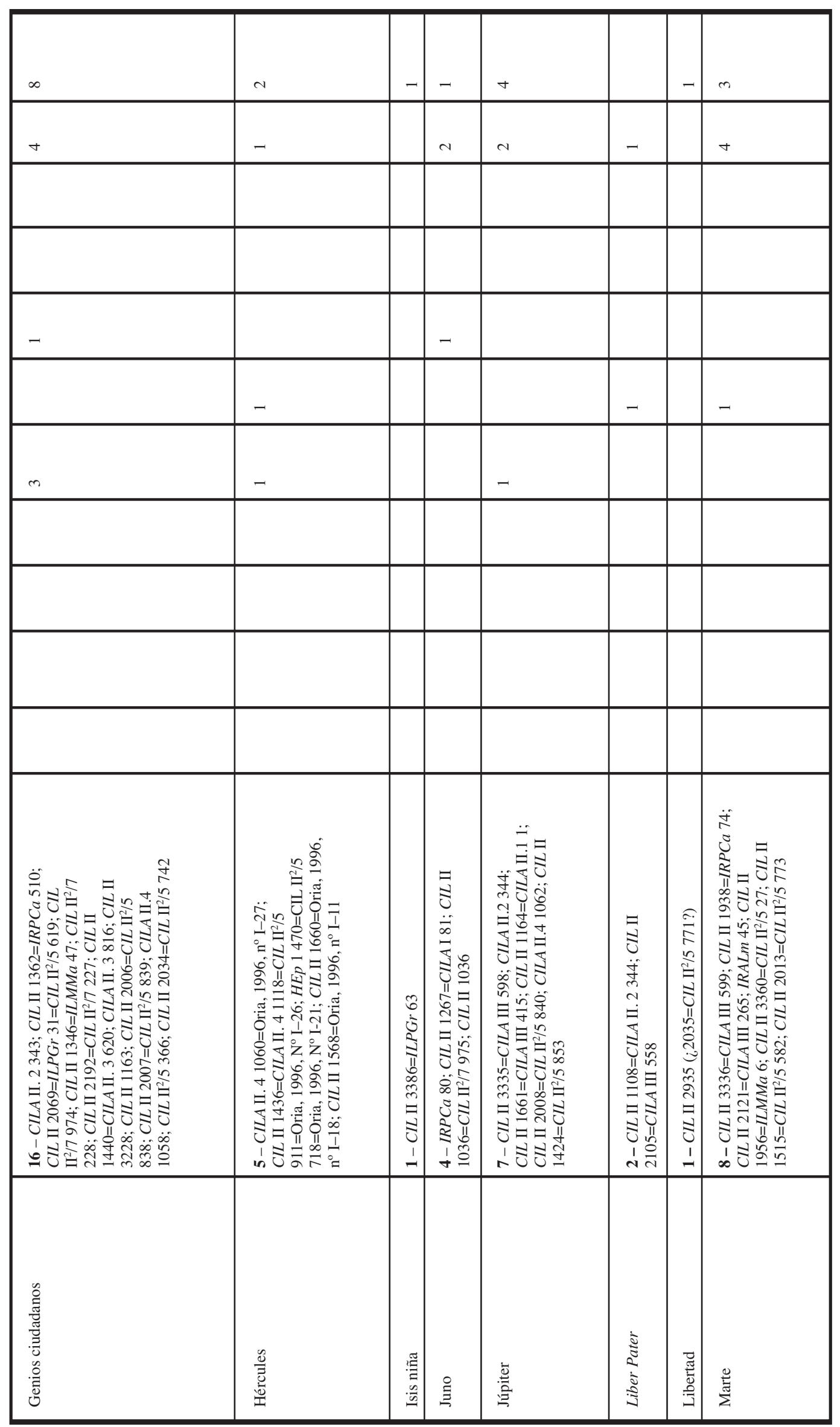




\begin{tabular}{|c|c|c|c|c|c|c|c|c|c|c|c|c|c|c|}
\hline$\sim$ & 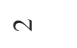 & -1 & - & - & & - & - & & - & & $N$ & & - & F \\
\hline & $\alpha$ & & & - & - & $m$ & & - & & & $N$ & $N$ & $\sim$ & లి \\
\hline & & & & & & & & & & & & & & - \\
\hline & & & & & & & & & & & - & & & T \\
\hline- & & & & & & & & & & & - & & & $a$ \\
\hline & & & & & & & & & & & & & - & $\varrho$ \\
\hline & & & & & & - & & & & & $N$ & & & $m$ \\
\hline- & & & & & & & & & & & & & & - \\
\hline & & & & & & & & & & - & & & & - \\
\hline 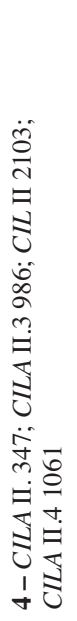 & 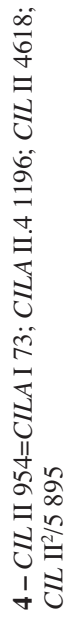 & 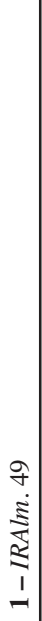 & 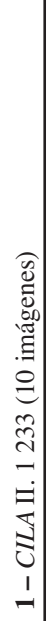 & 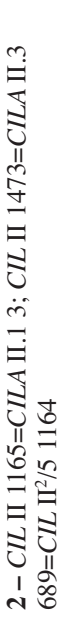 & 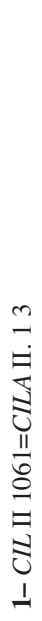 & 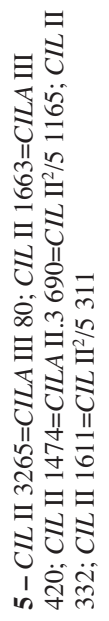 & 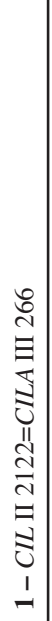 & 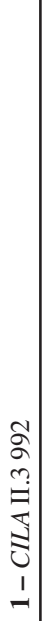 & 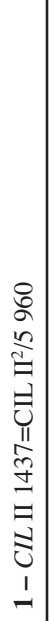 & 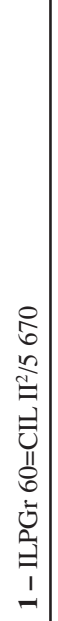 & 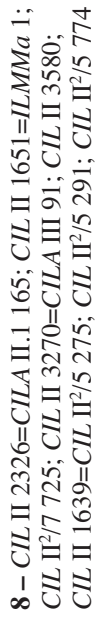 & 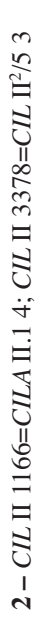 & 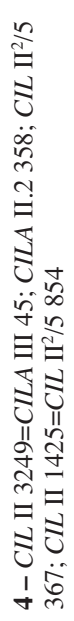 & $\stackrel{\prime}{=}$ \\
\hline 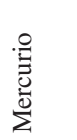 & 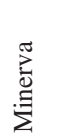 & 号 & $\begin{array}{l}\text { 离 } \\
\text { 艺 }\end{array}$ & 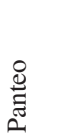 & $\tilde{\Xi}$ & 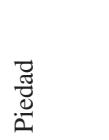 & $\stackrel{x}{\Rightarrow}$ & 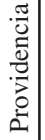 & 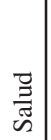 & 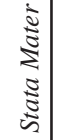 & $\stackrel{0}{\stackrel{0}{0}}$ & $\begin{array}{l}\frac{\pi}{5} \\
0\end{array}$ & & 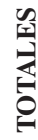 \\
\hline
\end{tabular}


panteón oficial romano, así como una figura femenina que no podemos identificar, pero cuya vestimenta y actitud son propias de los retratos honoríficos (León, 1995, $\mathrm{n}^{\circ}$ 17). La alternativa es considerarlo una plaza porticada o simplemente "gran espacio público" (León, 1995, 21-22), asociado o no al teatro.

En otras piezas el templo donde se sitúan las esculturas se menciona en la inscripción correspondiente. Así ocurre con el de Hércules dedicado en Osqua (HEp 1 470); con el Júpiter Panteo de Nescania (CIL II 2008) o con las donaciones de Cisimbrium e Ipolcobulcula (CIL II 2098 y 1649), estas dos a dioses no especificados e incluyendo una de ellas cinco estatuas. En ambos casos se destinan a un templo situado en un foro, formando todos ellos (templo, foro y estatuas) parte de la donación. Las dos estatuas de plata de Genios ciudadanos, dedicadas en el templo de Tutela de Corduba, se incluyen también en este apartado. Por el lugar de hallazgo de la inscripción, Stylow (1990, 271-272) piensa que el templo pudo situarse en la zona que hoy ocupa el centro comercial de la Avda. Gran Capitán; es decir, fuera de los dos foros ciudadanos que él mismo propone.

También hay epígrafes hallados in situ o en las cercanías del templo correspondiente. Dos lotes de pedestales nos permiten reconstruir el "paisaje escultórico" de templos muy destacados: el Traianeum de Italica y el gran santuario que domina Munigua. En el primero se dedican estatuas a Apolo Augusto (CILA II.2, 342), al Genio de la Colonia (CILA II.2, 343), a Júpiter (CILA II.2, 344) y a la Victoria Augusta (CILA II.2, 358), un conjunto de divinidades de marcado tono político, a tono con el Trajano colosal que presidiría el conjunto. León $(1995,24)$ sugiere con muchas dudas que quizás algunas esculturas tradicionalmente atribuídas a las termas de Los Palacios, como un torso de Diana (León, 1995, n 39), pertenezcan también al Traianeum, basándose en la amplitud e imprecisión del topónimo "Los Palacios".

En el segundo, los dioses son Fortuna Crescens (CILA II.4, 1057) y Hércules (CILA II.4, 1060), ambos Augustos. Es interesante la asociación de estas dos divinidades que en Italia comparten un apelativo poco común, Primigenio, conocido en la P. Ibérica por un pedestal de Hércules de Ostippo, así como otros varios que parecen casi específicos de ambas divinidades (Champeaux, 1975, 958 ss.). Precisamente, dos de los templos más destacados de Fortuna y Hércules en Italia son los de Praeneste y Tibur, de tipología muy parecida a la del templo de Munigua, con el que se han relacionado arquitectónicamente
(Coarelli, 1987). Coarelli vincula además ciertos rasgos constructivos de este último con el culto imperial, en relación con los dioses Augustos conocidos en la ciudad. También en Munigua se conserva otro pedestal (CILA II.4, 1061) en su colocación original, una edícula dedicada a Mercurio a la entrada del foro de la ciudad. Probablemente la dedicatoria a Hércules citada más atrás se refiera a un conjunto semejante.

\subsubsection{Los foros}

Los foros, como escenario característico de la representación pública, acogen con seguridad diez de las estatuas incluidas en las tablas, una mínima muestra de las que sin duda existieron. De hecho es muy probable que la mayoría de los 36 pedestales sin contexto, pero con un formulario propio de la epigrafía pública, correspondan a esculturas destinadas a foros. Este debe ser el caso de los dedicados a Bonus Euentus (CIL II 1471), Pantheus (CIL II 1473) y Pietas (CIL II 1474), hallados o conservados en varios lugares muy próximos entre sí del centro de Écija, en la zona donde puede situarse el foro de Astigi. Su unidad formal y de contenido indica su pertenencia a un conjunto, que sólo puede localizarse en un espacio público tan destacado como el principal centro cívico de la ciudad, o quizás también un recinto de culto imperial del que no tenemos otras noticias (estudio de conjunto en Chic, 1987-88); Mangas $(1991,125)$ propone también un templo o una sede colegial, a falta de la fórmula L.D.D.D. Otros dioses cuya dedicatoria implica una situación pública indeterminada son Apolo, Diana, Esculapio, Fortuna, varios Genios municipales / coloniales, Hércules, Juno, Júpiter, Liber Pater, Marte, Minerva, Paz, Piedad, Providencia, Venus, Vesta y Victoria: es decir, la mayor parte de los que son honrados mediante una estatua de la cual conservamos la dedicatoria.

La única escultura en contexto forense indudable es una cabeza de Dea Roma, hallada en Italica durante las excavaciones de Ivo de la Cortina en 1839 (León, 1995, n ${ }^{\circ}$ 49). En el de Munigua se han hallado además pedestales dedicados a Bonus Euentus (CILA II.4, 1054); Ceres (CIL II.4, 1055); Dis Pater, que realmente se encontraba en una de las salas anejas al foro, a modo de un pequeño recinto cultual (CILA II.4, 1056). Estas tres piezas ayudan a confirmar la situación de las ecijanas, muy semejantes en las características generales de sus dedicatorias e incluso en alguna de las divinidades incluidas. Además contamos con otros dioses como Hércules, al que se dedica un pedestal en nombre de Tiberio en Tucci (CILA II 1660); Liber 
Pater con CIL II 1108, de Italica; Marte (CIL II 1956), en una dedicatoria que no se encontró en el propio foro, sino que lo menciona como destino expreso de la escultura ofrecida por una sacerdotisa de Cartima; y Venus (CIL II $\left.\mathrm{I}^{2} / 5,774\right)$, a la que se levanta una estatua con sus adornos correspondientes en una sala junto al foro de Singilia.

Interesa destacar la variedad de dioses que ocupan un lugar en los foros, donde también se sitúan buena parte de los templos antes citados. Las divinidades esperables en tal contexto son las más ligadas al culto oficial, combinadas con las representaciones imperiales y los retratos honoríficos de notables locales (v. el estudio de conjunto de dos foros africanos en Zimmer, 1989). Su utilización como elemento de propaganda no elimina su valor religioso (Alföldy, $1981,198)$, puesto que se convierten a la vez en manifestación de unos cultos cívicos que implican a la comunidad. En la Bética aparecen algunos de los más característicos del culto imperial, como las Virtudes, y otros de máxima popularidad en todo el mundo romano por su variedad de atribuciones o su destacado lugar en el panteón oficial, como Hércules, Mercurio, Diana o Venus. Pero también encontramos figuras poco habituales como Dis Pater o como el dios médico Esculapio, cuyo destino más esperable sería un templo o incluso unas termas, lugares relacionados con el cuidado del cuerpo. Seguramente y si dejamos aparte los cultos puramente políticos, es la popularidad del dios en cuestión e incluso la devoción particular del dedicante la que justifica la dedicatoria de una estatua en un foro. Cuando a su nombre se le añade además el apelativo "Augusto", que lo vincula de forma más o menos vaga al "círculo" de dioses protectores del emperador (Fishwick, 1991, 446 ss.), ya podemos decir que se encuentra listo para integrarse en el panteón ciudadano con todos los honores.

\subsubsection{Los teatros}

De siete dioses más sabemos que formaban parte de la decoración de teatros, algunos en más de una ocasión. Las piezas, estatuas o pedestales, halladas en contexto son relativamente frecuentes en este caso. Así ocurre con el grupo de dioses encontrados alrededor de la estructura tras la summa cauea del de Italica, aunque ya hemos visto que su relación con el mismo es problemática y que hay otras interpretaciones del complejo arquitectónico y escultórico. Las piezas aparecidas son la Venus, el Mercurio y la más completa y conocida de las esculturas de Diana de Italica, así como otro torso menor de esta diosa que no hemos incluido en las tablas. Si efectivamente existe relación entre esta estructura porticada y el teatro, éste sería probablemente el mejor conocido en su programa decorativo de toda la Bética, ya que se conservan igualmente las dos ninfasfuente que decoraban el proscenio (León, 1995, $\mathrm{n}^{\mathrm{o}}$ 56-57). Todas ellas, junto con varias aras decoradas (v. sobre éstas Luzón, 1978), forman el lote más completo de esculturas teatrales localizadas en contexto dentro de la Bética.

De otras dos ninfas-fuente cordobesas puede suponerse con toda verosimilitud que pertenezcan al teatro, ya que se encontraron en su entorno inmediato (Loza, 1993). Se relacionan directamente con otros personajes mitológicos como los Silenos recostados sobre un odre, encontrados en los mismos contextos y con funciones similares (Loza, 1994). La única connotación religiosa de estas figuras es su relación con el culto dionisíaco, tan vinculado al ambiente teatral desde los orígenes de éste (v. Bieber, 1961). De hecho, Loza (1994, 280-281) propone interpretar las ninfas del teatro de Italica como ménades, relacionándolas con la decoración de las conocidas aras neoáticas.

A falta de las estatuas, conservamos al menos dos pedestales encontrados en el de Regina, dedicados respectivamente al Genio (CIL $\mathrm{II}^{2} / 7$ 974) y a Juno (CIL II $1036=$ CIL II ${ }^{2} / 7$ 975). En Castulo no conservamos la escultura y ni siquiera el pedestal de la misma, pero sí el de un notable local entre cuyos méritos se cuenta haber donado para el teatro una imagen de Venus Genetrix, acompañada por otra de su hijo Cupido, según indicación expresa en el texto (CIL II 3270).

En el repertorio de dioses relacionados con los teatros béticos (en general sobre la estatuaria teatral, Fuchs, 1987) podemos establecer una distinción clara: divinidades menores en esculturas de carácter ornamental, las ninfas-fuentes acompañadas de Silenos, e imágenes de dioses del panteón oficial, entre las cuales se muestra cierta preferencia por las de contenido político. Así, la Venus de Cartima acompañada de su hijo es expresamente la Genetrix de la familia Julia. Juno, reina del panteón romano e integrante de la Tríada Capitolina, flanquea junto al Genio municipal el escenario de Regina. Esta situación no es de extrañar, si se tiene en cuenta que los teatros, como lugar de encuentro de la comunidad ciudadana, son también uno de los centros privilegiados del culto imperial (v. Gros, 1990). De la complejidad de la decoración en el entorno de los teatros es buena muestra el llamado "complejo pompeyano del Campo Marzio" (Coarelli, 1971-1972), donde figuras alusivas al ambiente teatral y al culto de Venus se mezclan con las de 
carácter político, combinándose igualmente estilos artísticos diferentes.

\subsubsection{Las termas}

El lote de esculturas y pedestales de dioses encontrados o destinados a termas es más reducido, sobre todo porque la mayor parte la forman las piezas localizadas en las de Munigua: Minerva, un Genio joven conocido como Bonus Euentus, la "Hispania" que se identifica en realidad con una Venus o ninfa y otro torso femenino de posible ninfa, además de un retrato y otros fragmentos menores (Hertel, 1993, $\mathrm{n}^{\mathrm{O}}$ 4-7, 12, 25, 29). Hertel $(1993,99)$ piensa que quizás las piezas no decoraban originalmente el edificio, sino que se depositaron allí a posteriori para fabricar con ellas cal. Sin embargo, que las representaciones sean heterogéneas no es motivo para descartar su pertenencia a las termas, recintos cuya decoración incluye habitualmente toda clase de dioses, semidioses, retratos, etc. en forma de estatuas exentas, hermas, relieves, etc. (v. en general Manderscheid, 1981).

Fuera de ese grupo quedan las piezas atribuidas a las termas de Los Palacios en la uetus urbs de Italica, una Diana (León, 1995, no 39) y dos torsos de Mercurio (id., n ${ }^{\circ}$ 34, 36, quizás más bien imágenes de Meleagro que de Mercurio); un dios-río localizado en Fuengirola (Rodríguez Oliva, 1978, $\mathrm{n}^{\mathrm{O}}$ 3) y un Cupido de Cartima, cuyo dedicante destinó de manera expresa "al pórtico de los baños construidos en un terreno de su propiedad" (CIL II 1956).

En las termas es donde más esculturas y menos pedestales se han localizado in situ. Esto indica que las termas no se consideran un lugar tan adecuado para donaciones públicas como las que los pedestales mencionan, aunque sí se decoran profusamente con una gran variedad de dioses, desde los más venerados en los ambientes oficiales hasta las Ninfas y el dios-río que podemos considerar "de repertorio" y especialmente adecuados para el ambiente termal. Manderscheid (1981, 29-30) distingue claramente entre el sentido casi religioso de los dioses presentes en los gimnasios griegos y la amalgama de dioses con diferente función, agrupados más con carácter decorativo que programático en las termas romanas, aunque no podemos descartar determinadas asociaciones y alusiones. P.e., destacamos la presencia de dos posibles Mercurios (o quizás más bien Meleagros) en las italicenses termas de Los Palacios, ya que como Hércules, que frecuentemente se le asocia en estos contextos, es una divinidad muy vinculada al mundo de los jóvenes atletas. A ambos suelen asimilarse, incluso en la iconografía, las representaciones de atletas vencedores en triunfo (Rausa, 1994, 167).

La decoración de espacios públicos con estatuas de dioses es una práctica ajena a la tradición prerromana de la Bética, tanto en el aspecto más puramente religioso como en el ornamental y propagandístico. En una región donde apenas se conocen con seguridad representaciones de dioses, menos aún como imágenes de culto monumentales, un santuario de amplia proyección como el de Hércules Gaditano constituye una destacada excepción por los ricos exvotos acumulados, bastantes de ellos escultóricos. Las estatuas halladas en los santuarios ibéricos de Sierra Morena son igualmente exvotos e identificar dioses entre ellos es cuando menos arriesgado, como ocurre también con imágenes en tumbas tan destacadas como la Dama de Baza (v. en general Oria, e.p.). En cualquier caso predominan los contextos religiosos, ya sean lugares de culto o enterramiento, lo que lleva a pensar que las estatuas en cuestión sí que presentan implicaciones en ese sentido. Por el contrario, los dioses romanos se reconocen en unas iconografías sin atributos locales, que se utilizan siguiendo pautas diferentes.

Las esculturas monumentales de dioses en la Bética se presentan de forma mayoritaria en ambientes urbanos, formando parte de la decoración de los edificios públicos. Es cierto que la mayoría de la información se concentra en unas pocas ciudades, excavadas desde antiguo y en algunos casos con proyectos sistemáticos de los últimos tiempos que han permitido conocerlas relativamente a fondo. Así ocurre con Munigua y Baelo Claudia, cuya situación es tan diferente a la de Italica o a la de ciudades hoy habitadas que se conocen de manera fragmentaria, por abundante que sea la documentación: Hispalis, Corduba, Astigi, Cartima y otros núcleos menores. La concentración de los datos en las ciudades más o mejor excavadas, si bien proporciona una información parcial, permite conocer en cambio un abanico de situaciones representativas, ya que las ciudades en cuestión abarcan prácticamente todas las posibilidades: capitales de provincia y conuentus, pequeños núcleos de origen indígena, diferentes dedicaciones económicas con las consiguientes diferencias en el nivel de riquezas, etc. Esto redunda sobre todo en el aspecto y calidad de las esculturas y los edificios en que se colocan, pero no modifica drásticamente el comportamiento común de sus responsables, las élites sociales y económicas.

Los lugares públicos en cuestión representan sin una clara delimitación tres facetas básicas de la vida ciudadana: la religiosa, en su aspecto cultual y votivo; la política o más genéricamente cívica, 
relativa al funcionamiento de las instituciones y también al encuentro y manifestación colectiva de los ciudadanos; y el servicio público, aproximadamente como hoy lo entendemos. Estas facetas apenas pueden deslindarse en la mayor parte de los casos, tanto dentro como fuera de la Bética. En los templos se combinan la función religiosa y la cívica / política, mientras edificios públicos de carácter civil (basílicas, monumentos conmemorativos, etc.) suman a este aspecto administrativo y de servicio público una faceta cultual ligada a los dioses protectores de la vida cívica y al culto imperial. Todas ellas se hacen presentes igualmente en los edificios de espectáculos, pero en cambio en foros, calles, pórticos y jardines es la vertiente "civil" la predominante, con alusiones religiosas p.e. en ciertos "jardines sagrados" de ambiente mitológico (v. Dräger, 1994, 140 ss.). Servicios como termas y fuentes presentan connotaciones salutíferas y cultuales, sobre todo en regiones con fuerte tradición de culto a las aguas donde a las termas se asocian con frecuencia santuarios (v. Aupert, 1991, con ejemplos sobre todo de Galia). No olvidemos por otra parte la sacralidad del espacio público en el mundo romano, desde el mismo momento de la delimitación territorial y la organización general de la ciudad (Zaccaria Ruggiu, 1995, 14-15 y en general, Cap. 1).

La localización mayoritaria de las estatuas béticas de dioses sigue sin alteraciones destacables este modelo, perfectamente encajado en el desarrollo urbano de la provincia. Por decirlo de un modo simple, los dioses esperables se encuentran en los lugares esperables dentro de las ciudades romanas, con la excepción de un par de divinidades poco comunes pero también muy itálicas, como Dis Pater y Stata Mater. Las conclusiones deben coincidir con las de otro reciente trabajo nuestro, que en realidad está planteado como precedente de éste (Oria, e.p.). Las estatuas de los dioses desempeñan en el ambiente de las ciudades hispanorromanas un importante papel como prueba de asimilación. Una buena parte tiene directas connotaciones religiosas, aunque no siempre puedan considerarse imágenes de culto: tanto las destinadas a templos, como las que se sitúan en foros y otros edificios cívicos con carácter de exvotos. Las asociaciones de dioses pueden variar, aunque el añadido del epíteto Augusto crea un nexo entre ellos en algunos templos y foros. Incluso cuando no son verdaderas imágenes cultuales, los cultos cívicos desarrollados al compás del proceso de municipalización pueden considerarse su causa última. En otros casos, las imágenes contribuyen a crear ambientes mitológicos cuya base literaria es bien conocida por las élites romanas y romanizadas. Además, la donación pública de estatuas divinas o de otro tipo es un elemento fundamental de las prácticas cívicas, como medio de obtener prestigio y posición. El contenido religioso y más aún la remota relación con las creencias locales prerromanas quedan en un segundo plano ante la proliferación de estas estatuas, que asimilan el paisaje de las ciudades béticas a las de Italia y el resto del Imperio.

\section{Bibliografía CitAda EN EL TRABAJO Y EN LAS TABLAS}

\section{CATÁLOGOS CITADOS EN FORMA ABREVIADA}

CIL II: HÜBNER, E. 1869: Corpus Inscriptionum Latinarum II. Inscriptiones Hispaniae Latinae. Berlín + HÜBNER, E. 1892: Corpus Inscriptionum Hispaniae Latinarum, Supplementum. Berlín.

CIL II²/5: STYLOw, A. U. et al., eds. 1998: Inscriptiones Hispaniae Latinae, ed. altera, fasc. $V$. Conventus Astigitanus. Berlín.

CIL II²/7: STYlow, A. U. et al., eds. 1995: Inscriptiones Hispaniae Latinae, ed. altera, fasc. VII. Conventus Cordubensis. Berlín.

CILA I: GonZÁlez, J. 1989: Corpus de Inscripciones Latinas de Andalucía I. Huelva. Sevilla.

CILA II.2: GonZÁlez, J. 1991: Corpus de Inscripciones Latinas de Andalucía II. Sevilla. Tomo II: La Vega (Itálica). Sevilla.

CILA II.3: GonZÁlez, J. 1996: Corpus de Inscripciones Latinas de Andalucía II. Sevilla. Tomo III: La Campiña. Sevilla.

CILA II.4: GonZÁlez, J. 1996: Corpus de Inscripciones Latinas de Andalucía II. Sevilla. Tomo IV: El Aljarafe, Sierra Norte, Sierra Sur. Sevilla.

EREP: GARCÍA Y BELLIDO, A. 1949: Esculturas romanas de España y Portugal. Madrid.

HeP: MANGAS, J., dir.: Hispania Epigraphica 1 (1991): Serie coordinada por la Universidad Complutense. Madrid.

Ilmma: Serrano, M. - Atencia, R. 1981: Inscripciones Latinas del Museo de Málaga. Madrid.

Ilpgr: PAstor, M. - MendozA, A. 1987: Inscripciones Latinas de la Provincia de Granada. Granada.

IRAlm: LÁZARO, R. 1980: Inscripciones Romanas en Almería. Almería.

IRPCa: GonZÁlEZ, J. 1982: Inscripciones Romanas de la Provincia de Cádiz. Cádiz.

\section{Artículos y Monografías}

ALFÖLDY, G. 1981: "Bildprogramme in den römischen Städten des Conventus Tarraconensis. Das Zeugnis 
der Statuenpostamente". Homenaje a García y Bellido IV. Revista de la Universidad Complutense 18, 177-275.

Aupert, P. 1991: "Les thermes comme lieux de culte", en Les thermes romains (Roma, 1988). Roma, 185-192.

BAENA, L. 1987: "Esculturas romanas de Málaga en colecciones particulares". BSAA LIII, 189-205.

BaliL, A. 1979: "Esculturas romanas de la Península Ibérica (III)". BSAAA XLV, 227-257.

BALIL, A. 1986: "Esculturas romanas de la Península Ibérica (VIII)”. BSAA LIII, 214-228.

BARTMAN, E. 1992: Roman sculptural copies in miniature. Leiden.

BeLloni, G. G. 1986: "Dis Pater", en Lexicon Iconographicum Mythologiae Classicae (LIMC), vol. III.1. ZurichMunich, 644.

Beltrán J. 1996: "El "Hércules en reposo" en la escultura romana de Andalucía”. Habis 27, 123-156.

BIEBER, M. 1961: The history of Greek and Roman theater. Princeton.

Blanco, A. et al. 1972: "Exavaciones en Cabra (Córdoba). La Casa del Mitra”. Habis 3, 297-319.

Blanco, A. 1982-83: "La cabeza de Vulcano del Museo Arqueológico de Córdoba”. Corduba 13, 27-33.

Blanco, A. 1988: "Hallazgos epigráficos", en LEÓN, P.: El Traianeum de Itálica. Sevilla, 103-117.

BlázQuez, J. Mo 1956: "Cabeza de Ceres en la colección Arrese (Corella, Navarra)”. Zephyrus XII, 229 ss.

CAIN, H. U. 1995: "Hellenistische Kultbilder. Religiöse Präsenz und museale Präsentation der Gőätter im Heiligtum und beim Fest”, en Wörrele, M. Zanker, P., eds.: Stadtbild und Bügerbild im Hellenismus (Munich, 1993). Munich, 115-130.

Canciani, F. 1994: "Stata Mater", Lexicon Iconographicum Mythologiae Classicae (LIMC), vol. VII.1. ZurichMunich, 808-809.

Champeaux, J. 1975: “Primigenius, ou de l'originaire". Latomus 34-2, 909-985.

CHIC, G. 1987-88: "Datos para el estudio del culto imperial en la Colonia Augusta Firma Astigi". Habis 1819, 365-381.

CoARelli, F. 1971-1972: "Il complesso pompeiano del Campo Marzio e la sua decorazione scultorea”. Atti della Pontificia Accademia Romana di Archeologia. Rendiconti XLIV, 99-122.

CoARelli , F. 1987: "Munigua, Praeneste e Tibur. I modelli laziali di un municipio della Baetica". Lucentum VI, 91-100.

COARELli , F. 1990/1996: "Cultura artistica e società" y
"La cultura figurativa", en Storia di Roma II.1, L'impero mediterraneo. Turín, 1990, 159-185 y 631670/refundidos como "La cultura artistica a Roma in età repubblicana. IV-II secolo a.C.”, en Revixit ars. Arte e ideologia a Roma. Dai modelli ellenistici alla tradizione repubblicana. Roma, 15-84.

DrÄGER, O. 1994: Religionem significare. Studien zu reich verzierten römischen Altären und Basen aus Marmor. Römische Mitteilungen Ergänzungshefte $n^{0} 33$. Mainz.

FEARS, J. R. 1981: "The cult of Virtues and Roman imperial ideology”, $A N R W$ II, 17.2. Berlín-Nueva York, 827-948.

Fernández-Chicarro, C. - Fernández, F. 1980: Catálogo del Museo Arqueológico Provincial de Sevilla. Sevilla.

FISHWICK, D. 1991: The imperial cult in the Latin West, vol. II.1. Leiden.

Fuchs, M. 1987: Untersuchungen zur Ausstattung römischer Theater. Mainz.

Gregory, A. 1994: "Powerful images: responses to portraits and the political uses of images in Rome". JRA 7, 80-99.

Gros, P. 1990: "Théatre et culte impérial en Gaule Narbonnaise et dans la Péninsule Ibérique", en Trillmich, W. - Zanker, P., eds.: Stadtbild und Ideologie (Madrid, 1987). Munich, 381-390.

Grünhagen, W. 1976: "Eine Weihung für Dis Pater in Munigua". mm 17, 226-237.

Hertel, D. 1993: "Die Skulpturen", en Blech, M. et al.: Mulva III. Madrider Beiträge vol. 21. Mainz, 35-108.

Hesberg, H. von 1981: "Archäologische Denkmäler zu den römischen Göttergestalten”, ANRW II, 17.2. Berlín-Nueva York, 103-1119.

HÖLSCHER, T. 1994: Monumenti statali e pubblico. Roma.

Hoyo, J. del 1994: "Joyas en la Andalucía romana. Documentación epigráfica”. Actas del II Congreso de Historia de Andalucía (Córdoba, 1991). Córdoba, vol. III, 419-429.

Lahusen, G. 1992: “Ars humanissima. Zur Ikonologie des Materials der römischen Plastik und Skulptur”, en Fischer-Hansen, T. et al., eds.: Ancient portraiture: image and message. Acta Hyperborea $\mathrm{n}^{\mathrm{o}} 4$. Copenhagen, 173-195.

LEÓN, P. 1982: "Antigüedades romanas en la colección del Marqués de Aracena". Homenaje al Profesor Hernández Díaz. Sevilla, vol. I, 75-88.

LEÓN, P. 1995: Esculturas de Itálica. Sevilla.

LOZA, Ma L. 1993: "Estatuas-fuentes romanas de Colonia Patricia Corduba". AAC 4, 141-158. 
LozA, M ${ }^{\mathrm{a}}$ L. 1994: "El agua en los teatros hispanorromanos: elementos escultóricos”. Habis 25, 263-283.

LuZÓN, J. M ${ }^{\mathrm{a}}$ 1978: "Die neuattischen Rund-Aren von Italica", $M M$ 19, 272-289.

LUZÓN , J. Ma - LEÓN, P. 1974: "Esculturas romanas de Andalucía IV". Habis 5, 161-168.

ManderscheID, H. 1981: Die Skulpturenausstattung der kaiserzeitlichen Thermenanlagen. Berlín.

MANGAS, J. 1986: "Die römische Religion in Hispanien während der Prinzipatszeit". $A N R W$, vol. II, 18.1. Berlín-Nueva York, 276-344.

Mangas, J. 1991: “Pantheus en Hispania”, en GonZÁlez Román, C., ed.: La Bética en su problemática histórica (Granada, 1990). Granada, 111-131.

MARÍn, Ma C. - PADILlA, A. 1997: "Los relieves del "domador de caballos" y su significación en el contexto religioso ibérico". QuadPrehArqCast 18, 461-494.

Martin, H. G. 1987: Römische Tempelkultbilder. Roma.

MÉLIDA, J. R. 1925: Monumentos romanos en España, Madrid.

MiскокI, T. 1995: Sub specie deae. Les impératrices et princesses romaines assimilées à des déesses. Étude iconologique. Roma.

MoOrmann, E. 1988: La pittura parietale romana come fonte di conoscenza per la scultura antica. AssenWolfeboro (N. H.).

Niemeyer, H. G. 1968: Studien zur Statuarischendarstellung der römischen Kaiser. Berlín.

Olmos, R. 1991: "Nuevos enfoques y propuestas de lectura en el estudio de la iconografía ibérica”, en VilA, A., coord.: Arqueología. Madrid, 209-230.

OrIA, M. 1996: Hércules en Hispania, una aproximación. Serie Cornucopia $n^{\circ} 5$. Barcelona.

OrIA , M. 1998: "Menzioni di luogo nelle dediche di statue della Baetica romana", $X V^{\text {th }}$ International Congress of Classical Archaeology (Amsterdam, 1998). Allard Pierson Series n ${ }^{\circ} 12$. Amsterdam.

ORIA , M. e.p.: "La imagen de los dioses de la Turdetania a la Bética".

PAIRAUlt MASSA, F. H. 1992: Iconologia e politica nell'Italia antica. Milán.

PenA, Mª J. 1981: “Contribución al estudio del culto de
Diana en Hispania", en La religión romana en Hispania (Madrid, 1979), Madrid, 49-57.

Presdo, F. J. 1974: "Hallazgo romano en Algeciras". Habis 5, 189 ss.

RAUSA, F. 1994: L'immagine del vincitore. L'atleta nella statuaria greca dall'età arcaica all'ellenismo, Roma.

Rodríguez CoRTÉs, J. 1991: Sociedad y religión clásica en la Bética romana. Salamanca.

Rodríguez Hidalgo, J. M. - Keay, S. 1995: "Recent work at Italica", en Cunliffe, B. y KEAY, S. (eds.), Social complexity and the development of towns in Iberia. Oxford, 395-420.

Rodríguez Oliva, P. 1978: "Esculturas del conventus de Gades”. BSAA XLIV, 374-385.

Rodríguez Oliva, P. 1993: "Ciclos escultóricos en la casa y en la ciudad de la Bética”, en NogAlEs, T., ed.: Actas de la I Reunión sobre Escultura Romana en Hispania (Mérida, 1992). Mérida, 23-61.

Sillières, P. 1995: Baelo Claudia, une cité romaine de Baetica. Madrid.

StYlow, A. U. 1990: "Apuntes sobre el urbanismo de la Corduba romana”, en TRILLMICH, W. - ZANKER, P., eds.: Stadtbild und Ideologie (Madrid, 1987). Munich, 259-282.

Thelamon, F. - Schmitt-Pantel, P. 1983: "Image et histoire”, en Image et céramique grecque (Rouen, 1982). París, 9-20.

Vermeule, C. C. 1987: The cult images of imperial Rome. Roma.

VICKERS, M. 1987: "Dates, methods and icons", en BÉrARD, C. et al., eds.: Images et société en Grèce ancienne. Lausana, 19-25.

Wrede, H. 1981: Consecratio in formam deorum. Mainz.

ZACCARIA RugGiU, A. 1995: Spazio privato e spazio pubblico nella città romana. Collection de l'École Française de Rome $\mathrm{n}^{\circ}$ 120. Roma.

ZANKER, P. 1994: "Nouvelles orientations de la recherche en iconographie. Commanditaires et spectateurs", RA 1994-2, 281-293.

Zimmer, G. 1989: Locus datus decreto decurionum. Zur Statuenaufstellung zweier Forumsanlagen in römischen Afrika. Munich. 